\title{
Thermoterrabacterium ferrireducens gen. nov., sp. nov., a Thermophilic Anaerobic Dissimilatory Fe(III)-Reducing Bacterium from a Continental Hot Spring
}

\author{
ALEXANDER SLOBODKIN, ${ }^{1}$ ANNA-LOUISE REYSENBACH,${ }^{2}$ NATHALIE STRUTZ, ${ }^{3}$ \\ MICHAEL DREIER, ${ }^{3}$ AND JUERGEN WIEGEL ${ }^{1 *}$ \\ Department of Microbiology and Center for Biological Resource Recovery, University of Georgia, Athens, Georgia \\ 30602-2605'; Department of Biochemistry and Microbiology, Cook College, Rutgers University, New Brunswick, \\ New Jersey $08903^{2}$; and Institut für Mikrobiologie, Universität Göttingen, D-37077 Göttingen, Germany ${ }^{3}$
}

\begin{abstract}
A strain of a thermophilic, anaerobic, dissimilatory, Fe(III)-reducing bacterium, Thermoterrabacterium ferrireducens gen. nov., sp. nov. (type strain JW/AS-Y7 ${ }^{\mathrm{T}}$; DSM 11255), was isolated from hot springs in Yellowstone National Park and New Zealand. The gram-positive-staining cells occurred singly or in pairs as straight to slightly curved rods, 0.3 to 0.4 by 1.6 to $2.7 \mu \mathrm{m}$, with rounded ends and exhibited a tumbling motility. Spores were not observed. The temperature range for growth was 50 to $74^{\circ} \mathrm{C}$ with an optimum at $65^{\circ} \mathrm{C}$. The $\mathrm{pH}$ range for growth at $65^{\circ} \mathrm{C}$ was from 5.5 to 7.6 , with an optimum at 6.0 to 6.2. The organism coupled the oxidation of glycerol to reduction of amorphous $\mathrm{Fe}$ (III) oxide or $\mathrm{Fe}$ (III) citrate as an electron acceptor. In the presence as well as in the absence of $\mathrm{Fe}(\mathrm{III})$ and in the presence of $\mathrm{CO}_{2}$, glycerol was metabolized by incomplete oxidation to acetate as the only organic metabolic product; no $\mathrm{H}_{2}$ was produced during growth. The organism utilized glycerol, lactate, 1,2-propanediol, glycerate, pyruvate, glucose, fructose, mannose, and yeast extract as substrates. In the presence of $\mathrm{Fe}$ (III) the bacterium utilized molecular hydrogen. The organism reduced 9,10-anthraquinone-2,6-disulfonic acid, fumarate (to succinate), and thiosulfate (to elemental sulfur) but did not reduce $\mathrm{MnO}_{2}$, nitrate, sulfate, sulfite, or elemental sulfur. The $\mathrm{G}+\mathrm{C}$ content of the DNA was 41 mol\% (as determined by high-performance liquid chromatography). The 16S ribosomal DNA sequence analysis placed the isolated strain as a member of a new genus within the gram-type-positive Bacillus-Clostridium subphylum.
\end{abstract}

The use of $\mathrm{Fe}(\mathrm{III})$ as an electron acceptor by microorganisms has important environmental implications and may be associated with the evolution of microbial life $(19,25)$. Microorganisms which couple the oxidation of organic compounds with $\mathrm{Fe}(\mathrm{III})$ reduction are phylogenetically diverse, including members of the gamma and delta subclasses of Proteobacteria and gram-positive organisms (18), and may be subdivided into two physiological groups: those that completely oxidize multicarbon compounds to carbon dioxide and those that incompletely oxidize organic substances to acetate. The first group includes Geobacter (5, 20), Desulfuromonas (7), Desulfuromusa (18), and Geovibrio (6) species, while the second group includes Shewanella $(4,27,29)$, Pelobacter (22), Ferrimonas (28), and Bacillus (2) species.

Microbial Fe(III) reduction has been intensively studied in mesobiotic marine and freshwater anoxic sediments and submerged soils (21), but little is presently known about microbial reduction of $\mathrm{Fe}$ (III) in thermobiotic ecosystems. Some geological evidence from iron oxide deposits is suggestive of $\mathrm{Fe}(\mathrm{III})$ reducing thermophile activity $(13,14)$. Ferric iron reduction coupled to oxidation of acetate or molecular hydrogen has been described for microbial consortia of thermophilic microorganisms from different geothermal areas $(30,31)$. Thermophilic Fe(III) reducers available in pure culture so far include only the aerobic archaeon Sulfolobus acidocaldarius, which reduces ferric iron with elemental sulfur (3), and the obligately anaerobic Bacillus infernus, which is able to reduce Fe(III) with formate and lactate at temperatures between 40 and $65^{\circ} \mathrm{C}(2)$.

\footnotetext{
* Corresponding author. Mailing address: Department of Microbiology, 215 Biological Sciences Building, University of Georgia, Athens, GA 30602-2605. Phone: (706) 542-2651. Fax: (706) 542-2674. Electronic mail address: jwiegel@uga.cc.uga.edu.
}

In this paper we describe an anaerobic, dissimilatory, Fe(III)-reducing (eu)bacterial thermophile, Thermoterrabacterium ferrireducens gen. nov., sp. nov., which belongs to the Gram-type-positive Bacillus-Clostridium subphylum and which has been isolated from hot springs in Yellowstone National Park.

\section{MATERIALS AND METHODS}

Environmental samples. Mixed samples of sediment, water, and black and white stringy biomass were collected in September 1995 from several sites at Calcite Springs at Yellowstone National Park in Wyoming. The temperatures a the sampling sites ranged from 40 to $85^{\circ} \mathrm{C}$, and the $\mathrm{pH}$ ranged from 6.0 to 8.3 .

Media and cultivation. A basal medium used for enrichment, isolation, and cultivation of $\mathrm{Fe}$ (III)-reducing bacteria was prepared by the modified Hungate technique (17) under a $\mathrm{CO}_{2}(100 \%)$ gas phase. The basal medium contained (per liter of deionized water) $0.33 \mathrm{~g}$ of $\mathrm{KH}_{2} \mathrm{PO}_{4}, 0.33 \mathrm{~g}$ of $\mathrm{NH}_{4} \mathrm{Cl}, 0.33 \mathrm{~g}$ of KCl, $0.33 \mathrm{~g}$ of $\mathrm{MgCl}_{2} \cdot 2 \mathrm{H}_{2} \mathrm{O}, 0.33 \mathrm{~g}$ of $\mathrm{CaCl}_{2} \cdot 2 \mathrm{H}_{2} \mathrm{O}, 2.0 \mathrm{~g}$ of $\mathrm{NaHCO}_{3}, 3.0 \mathrm{ml}$ of glycerol, $10 \mathrm{ml}$ of vitamin solution (39), and $1 \mathrm{ml}$ of trace element solution. The trace element solution contained (per liter) $2.0 \mathrm{mmol}$ of $\left(\mathrm{NH}_{4}\right)_{2} \mathrm{Fe}\left(\mathrm{SO}_{4}\right)_{2} \cdot 6 \mathrm{H}_{2} \mathrm{O}, 2.0$ mmol of $\mathrm{Na}_{2} \mathrm{SO}_{4}, 1.0 \mathrm{mmol}$ of $\mathrm{CoCl}_{2} \cdot 6 \mathrm{H}_{2} \mathrm{O}, 1.0 \mathrm{mmol}$ of $\mathrm{NiCl}_{2} \cdot 6 \mathrm{H}_{2} \mathrm{O}, 0.5$ mmol of $\mathrm{MnCl}_{2} \cdot 4 \mathrm{H}_{2} \mathrm{O}, 0.5 \mathrm{mmol}$ of $\mathrm{ZnSO}_{4} \cdot 7 \mathrm{H}_{2} \mathrm{O}, 0.5 \mathrm{mmol}$ of $\mathrm{Na}_{2} \mathrm{SeO}_{3}, 0.1$ mmol of $\mathrm{Na}_{2} \mathrm{MoO}_{4} \cdot 2 \mathrm{H}_{2} \mathrm{O}, 0.1 \mathrm{mmol}$ of $\mathrm{Na}_{2} \mathrm{WO}_{4} \cdot 2 \mathrm{H}_{2} \mathrm{O}, 0.1 \mathrm{mmol}$ of $\mathrm{H}_{3} \mathrm{BO}_{3}$, and $0.01 \mathrm{mmol}$ of $\mathrm{CuCl}_{2} \cdot 2 \mathrm{H}_{2} \mathrm{O}$. The $\mathrm{pH}$ was adjusted to 7.0 at $25^{\circ} \mathrm{C}\left(\mathrm{pH}^{25 \mathrm{C}}\right)$ with $10 \%$ (wt/vol) $\mathrm{NaOH}$. No reducing agent was added to the medium. Fe(III) was provided in the form of amorphous Fe(III) oxide at ca. $90 \mathrm{mmol}$ of $\mathrm{Fe}$ (III) per liter of medium. The amorphous Fe(III) oxide was synthesized by titrating a solution of $\mathrm{FeCl}_{3}$ with $10 \%$ (wt/vol) $\mathrm{NaOH}$ to $\mathrm{pH} 9.0$. The $\mathrm{pH}^{65 \mathrm{C}}$ of the autoclaved medium was 6.8 to 6.9

Unless otherwise noted, enrichment and pure cultures were grown in $10 \mathrm{ml}$ of medium in Hungate tubes under an atmosphere of $\mathrm{CO}_{2}(100 \%)$. All transfers and samplings of the cultures were performed with syringes and needles. The medium was heat sterilized at $135^{\circ} \mathrm{C}$ for $30 \mathrm{~min}$. All incubations were at $65^{\circ} \mathrm{C}$ unless otherwise noted.

Determination of growth. Growth of bacteria in medium containing amorphous Fe(III) oxide or other insoluble compounds was determined by direct counting with a phase-contrast microscope and a Petroff-Hausser chamber (Hausser Scientific Partnership, Horsham, Pa.). In media with soluble components, growth was determined by counting and by measuring the increase in optical density at $600 \mathrm{~nm}\left(\mathrm{OD}_{600}\right)$ (Spectronic 21; Bausch \& Lomb, Rochester. N.Y.). 
Temperature, $\mathrm{pH}$, and $\mathrm{NaCl}$ concentration ranges. Temperature ranges for growth and $\mathrm{Fe}(\mathrm{III})$ reduction were determined in basal medium by using a temperature gradient incubator (Scientific Industries, Inc., Bohemia, N.Y.) with shaking ( 15 strokes per min). The $\mathrm{pH}$ range for growth was determined at $65^{\circ} \mathrm{C}$. The basal medium was modified by omitting amorphous $\mathrm{Fe}(\mathrm{III})$ oxide and adding yeast extract ( $5 \mathrm{~g} /$ liter $)$, fumarate $(20 \mathrm{mM})$, and either morpholinethanesulfonic acid (MES) or HEPES (10 mM); $\mathrm{N}_{2}(100 \%)$ was used as the gas phase. The $\mathrm{pH}$ was adjusted with sterile stock solutions of $\mathrm{HCl}$ or $\mathrm{NaOH}$ at $65^{\circ} \mathrm{C}$ and measured with a model $815 \mathrm{MP}$ pH meter (Fisher Scientific, Pittsburgh, Pa.) equipped with a temperature probe and calibrated at $65^{\circ} \mathrm{C}$. The effect of $\mathrm{NaCl}$ on growth and $\mathrm{Fe}$ (III) reduction was determined in basal media containing $0,0.5$, $1.0,1.5$, and $2.0 \%(\mathrm{wt} / \mathrm{vol}) \mathrm{NaCl}$.

Substrate utilization. The ability of the organism to grow on different substrates was determined in basal medium in which the glycerol was replaced by autoclaved or filter-sterilized substrates, both in the presence and in the absence of amorphous $\mathrm{Fe}$ (III) oxide. When Fe(III) was omitted, the medium was prereduced with $\mathrm{Na}_{2} \mathrm{~S} \cdot 9 \mathrm{H}_{2} \mathrm{O}(0.5 \mathrm{~g} /$ liter $)$. The potential for molecular hydrogen to serve as an electron donor was studied in $60-\mathrm{ml}$ flasks containing $10 \mathrm{ml}$ of medium and with $\mathrm{H}_{2}-\mathrm{CO}_{2}(80: 20$ or $5 \%: 95 \%$ [vol/vol] $)$ as the gas phase. In experiments with elemental sulfur, basal medium was supplemented with acetate ( $3 \mathrm{~g} / \mathrm{liter}$ ) and yeast extract $(0.5 \mathrm{~g} /$ liter $)$ as carbon sources and elemental sulfur $(150 \mathrm{mM})$. The cultures were incubated for 2 weeks, and substrate utilization was monitored by measuring growth, $\mathrm{Fe}(\mathrm{II})$ accumulation, or acetate production. A medium in which the organic carbon source had been omitted was used as a control.

Electron acceptors. The potential use of different electron acceptors was studied in the basal medium containing glycerol $(30 \mathrm{mM})$ as a sole electron donor but lacking amorphous Fe(III) oxide. The different electron acceptor were added from autoclaved stock solutions. The medium was prereduced with $\mathrm{Na}_{2} \mathrm{~S} \cdot 9 \mathrm{H}_{2} \mathrm{O}(0.5 \mathrm{~g} /$ /iter $)$ in the experiments with sulfate, sulfite, thiosulfate, elemental sulfur, and fumarate. No reducing agent was present in media containing $\mathrm{O}_{2}, \mathrm{Fe}$ (III) citrate, $\mathrm{MnO}_{2}$, or 9,10-anthraquinone-2,6-disulfonic acid Both reduced and reducing-agent-free media were used in nitrate-amended experiments. Cultures grown with glycerol in prereduced basal medium without an electron acceptor were used as inocula $(10 \%$ [vol/vol]). The use of the electron acceptors was monitored by measuring growth (for all acceptors), by sulfide production (for sulfate, sulfite, thiosulfate, and elemental sulfur), by high-performance liquid chromatography (HPLC [for fumarate]), and by measuring changes in the visible color of the medium or precipitate [for $\mathrm{Fe}$ (III) citrate, $\mathrm{MnO}_{2}, 9,10$-anthraquinone-2,6-disulfonic acid, and thiosulfate].

Antibiotic susceptibility. Susceptibility to antibiotics was determined by transferring an exponentially growing culture into fresh basal medjum containing 100 $\mu \mathrm{g}$ of filter-sterilized antibiotic per ml. The cultures were incubated at $50^{\circ} \mathrm{C}$ for 2 weeks.

Microscopy. Routine examinations and cell counting were performed with a light microscope (model PM 10AD [Olympus Optical Co., Ltd., Tokyo, Japan] equipped with phase-contrast optics). Transmission electron microscopy was performed with a model JEM-100 CXII electron microscope (JEOL, Tokyo Japan). The samples used for ultrathin sectioning were prepared by poststaining with uranyl acetate and lead citrate as described by Spurr (32). Gram staining was performed by the method of Hucker as described by Doetsch (10).

Analytical techniques. Fe(III) reduction was monitored by measuring the accumulation of $\mathrm{Fe}(\mathrm{II})$ over time. $\mathrm{Fe}$ (II) was measured by adding a $0.5-\mathrm{m}$ sample from the culture to $5 \mathrm{ml}$ of $0.6 \mathrm{~N} \mathrm{HCl}$. After $24 \mathrm{~h}$ of extraction, $\mathrm{HCl}$ soluble $\mathrm{Fe}$ (II) was determined with $2,2^{\prime}$-dipyridyl (1). Sulfide was determined by the method of Cord-Ruwisch (8). Determination of glycerol, short-chain organic acids, and alcohols was performed by HPLC as previously described (33). Molecular hydrogen was analyzed by gas chromatography (33)

$\mathbf{G}+\mathrm{C}$ content of DNA. The DNA was isolated and purified by the $\mathrm{NaOH}$ method of Mesbah et al. (24). The DNA was digested enzymatically, and the guanine-plus-cytosine $(\mathrm{G}+\mathrm{C})$ content was determined by separating the nucleosides by HPLC as described by Whitman et al. (36) and Mesbah et al. (24).

Extraction and sequencing of DNA and analysis of $16 \mathrm{~S}$ rRNA genes. The genomic DNA was extracted from cell pellets by standard methods (23). The $16 \mathrm{~S}$ ribosomal DNA (16S rDNA) was amplified by PCR as described previously (11). The double-stranded PCR products were sequenced by cycle sequencing with an ABI 373 automated sequencer. The 16 S rDNA sequences were aligned manually with a representative set of $16 \mathrm{~S}$ rRNA sequences obtained from the Ribosomal Database Project or from recent GenBank releases. The secondary structure was used as a guide to ensure that only homologous regions were compared. A tota of 1,503 nucleotides were sequenced, and 1,202 were used in the phylogenetic analysis. The absence of chimeric molecules was ensured by using the secondary structure and computer analyses. The phylogenetic trees were constructed eithe with evolutionary distance matrices, using the algorithm of De Soete (9), or by maximum-likelihood analysis, using the program fastDNAml (26). Bootstrap values were obtained for maximum-likelihood analysis by using 100 replicate trees and random addition of sequence.

Nucleotide sequence accession number. The 16S rDNA sequence of strain JW/AS-Y $7^{\mathrm{T}}$ has been deposited in GenBank under accession number U76363.

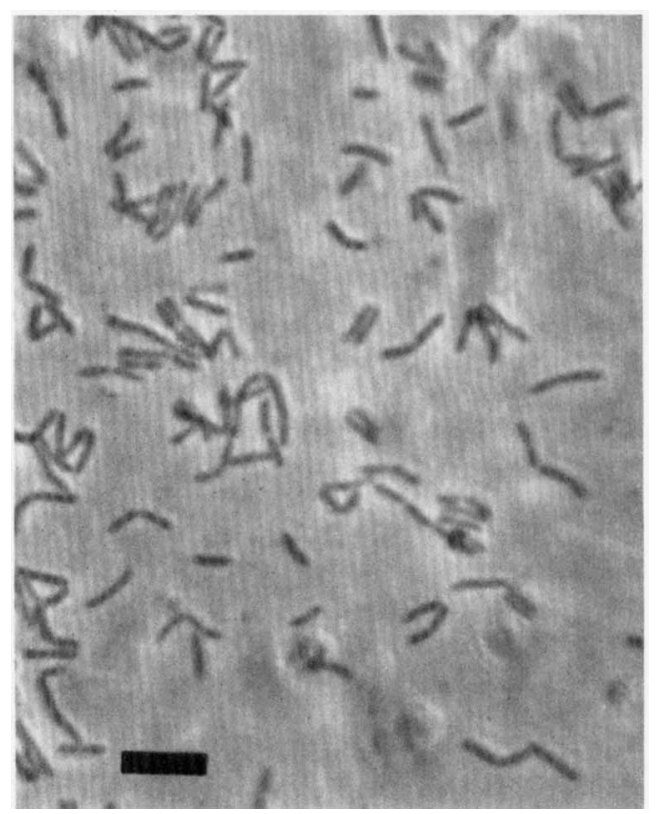

FIG. 1. Phase-contrast light micrograph showing the cell morphology of strain JW/AS-Y $7^{\mathrm{T}}$. Growth was on basal medium with 9,10-anthraquinone-2,6 disulfonic acid as an electron acceptor. Bar $=5 \mu \mathrm{m}$.

\section{RESULTS}

Enrichment and isolation. Eleven samples obtained from thermal areas in Yellowstone National Park were used for enrichment of thermophilic dissimilatory Fe(III)-reducing microorganisms (see Materials and Methods). Basal anaerobic medium, in which glycerol was a potential electron donor and amorphous $\mathrm{Fe}$ (III) oxide was provided as an electron acceptor, was inoculated with $10 \%$ (wt/vol) of the sample and incubated at 60 and $65^{\circ} \mathrm{C}$ in the dark. After 48 to $72 \mathrm{~h}$ of cultivation, in four enrichments from Calcite Springs samples, nonmagnetic brown amorphous Fe(III) oxide was converted to a black solid material of less volume which was strongly attracted to a magnet and contained a significant amount of $\mathrm{Fe}(\mathrm{II})$. For the isolation of a pure culture, the enrichment with the fastest rate of $\mathrm{Fe}$ (III) reduction (sampling point, $72^{\circ} \mathrm{C} ; \mathrm{pH}^{25 \mathrm{C}}, 7.5$ ) was chosen. After three successive 10\% (wt/vol) transfers, the enrichment was repeatedly serially diluted to extinction in the basal medium. The highest dilution that was positive for $\mathrm{Fe}$ (III) reduction $\left(10^{-7}\right)$ was serially diluted to extinction in agar shake tubes (1.5\% Bacto Agar) in the glycerol-containing basal medium in which $\mathrm{Fe}$ (III) oxide was omitted and $\mathrm{Na}_{2} \mathrm{~S} \cdot 9 \mathrm{H}_{2} \mathrm{O}(0.5 \mathrm{~g} /$ liter $)$ was provided as a reducing agent. Single colonies were removed and subcultured in liquid medium with glycerol and amorphous $\mathrm{Fe}$ (III) oxide. This process was repeated twice, after which the culture was considered to be pure and was designated as strain JW/AS-Y $7^{\mathrm{T}}$. Some other, similar Fe-reducing strains with similar morphology were isolated. Their taxonomic positions and physiology are under further investigation.

Colony and cell morphology. In agar shake cultures, colonies appeared after 2 to 3 days. The colonies were uniformly round, 0.5 to $0.8 \mathrm{~mm}$ in diameter, and nonpigmented. The cells of strain JW/AS-Y $7^{\mathrm{T}}$ were straight to slightly curved rods, 0.3 to $0.4 \mu \mathrm{m}$ in diameter and 1.6 to $2.7 \mu \mathrm{m}$ in length, with rounded ends (Fig. 1). The cells occurred singly or in pairs and exhibited a tumbling motility. The formation of spores was not observed. 

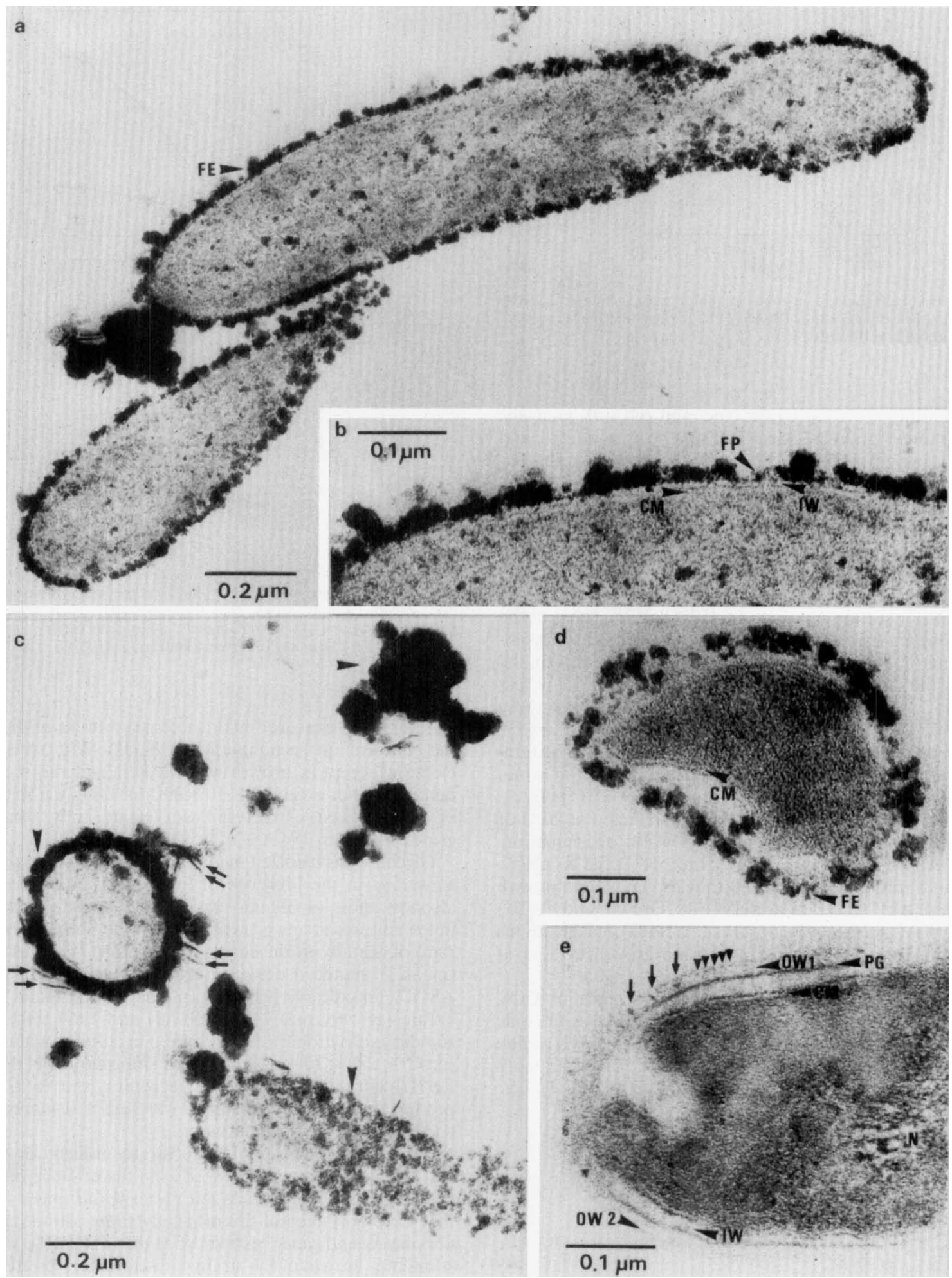

FIG. 2. Electron micrographs from ultrathin sections of cells of strain JW/AS-Y7 $7^{\mathrm{T}}$. Growth was on basal medium with amorphous Fe(III) oxide as an electron acceptor. (a) The cells are elongated rods covered by a layer of very electron-dense particulate material (FE). (b) The electron-dense particulate material (FP) appears to be precipitated on the outside of an electron-transparent wall layer (IW); CM, cytoplasmic membrane. (c) Electron-dense material (arrowheads) is not only present at the cell surface but is also detached from the cells. The three groups of two arrows each point to electron-dense material which appears to have the shape of platelet or needles. (d) Cells in a state of plasmolysis. Although the cytoplasmatic membrane (CM) is retracted from the wall, the electron-dense material, together with the wall layers, forms a shell-like structure (FE). (e) Sections through the pole of a cell with only very minor amounts of electron-dense material (three arrows). The cell envelope is composed of the cytoplasmic membrane (CM), an electron-transparent inner wall layer (IW) which may have been artificially formed by partial plasmolysis, an electron-dense layer (PG) most probably made up of peptidoglycan, an electron-transparent outer wall layer (OW1), and an electron-dense outermost wall layer (OW2). Note that formation of the electron-dense particulate material begins in OW1. Small arrowheads point to regularly arranged intensity maxima, indicating the presence of an $\mathrm{S}$ layer. $\mathrm{N}$, nucleoid. 


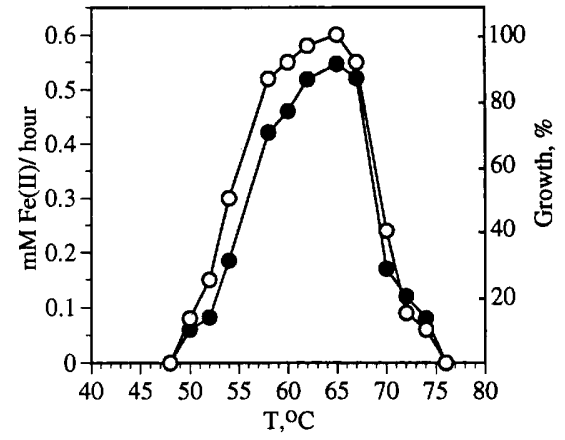

FIG. 3. Effect of temperature on growth of (empty circles) and rate of $\mathrm{Fe}$ (II) production by (filled circles) strain JW/AS-Y $7^{\mathrm{T}}$. One hundred percent growth was equivalent to $6.2 \times 10^{8}$ cells $/ \mathrm{ml}$ after $72 \mathrm{~h}$ of incubation.

Gram staining reaction, Gram type, and cell wall analysis. The cells stained gram positive in both the exponential and stationary growth phases. The cell wall structure of strain JW/ AS-Y $7^{\mathrm{T}}$ (Fig. 2e) and the absence of a positive reaction in the lipopolysaccharide-polymyxin B assay of Wiegel and Quandt (38) are consistent with it being a Gram-type-positive organism (37). This is in agreement with the 16S rRNA sequencing data which placed the organism in the Clostridium-Bacillus subphylum.

The ultrathin sectioning of strain JW/AS-Y $7^{\mathrm{T}}$ grown in the medium with amorphous $\mathrm{Fe}$ (III) oxide revealed that a prominent feature of the cells is the presence of dark deposits on the outside of the cell wall (Fig. 2a to e). Electron energy loss spectroscopy analysis confirmed the presence of iron in these deposits.

Temperature, $\mathrm{pH}$, and $\mathrm{NaCl}$ concentration ranges. The temperature range for growth of and $\mathrm{Fe}$ (III) reduction in strain JW/AS-Y $7^{\mathrm{T}}$ was 50 to $74^{\circ} \mathrm{C}$, with an optimum at $65^{\circ} \mathrm{C}$ (Fig. 3). No growth and no $\mathrm{Fe}$ (III) reduction were detected at $76^{\circ} \mathrm{C}$ or at temperatures of $48^{\circ} \mathrm{C}$ or lower after 3 weeks of incubation. Strain JW/AS-Y $7^{\mathrm{T}}$ grew in a range from $\mathrm{pH}^{65 \mathrm{C}} 5.5$ to $\mathrm{pH}^{65 \mathrm{C}}$ 7.6, with an optimum at $\mathrm{pH}^{65 \mathrm{C}} 6.0$ to 6.2 (Fig. 4). No growth was detected at $\mathrm{pH}^{65 \mathrm{C}} 5.3$ or at $\mathrm{pH}^{65 \mathrm{C}} 7.8$. Growth and $\mathrm{Fe}$ (III) reduction of JW/AS-Y $7^{\mathrm{T}}$ was observed at $\mathrm{NaCl}$ concentrations ranging from 0 to $1.0 \%$ (wt/vol), with no growth evident at $1.5 \%(\mathrm{wt} / \mathrm{vol})$.

Growth and $\mathrm{Fe}(\mathrm{III})$ reduction. In the presence of $\mathrm{CO}_{2}$, strain JW/AS-Y $7^{\mathrm{T}}$ grew anaerobically with glycerol as the only organic carbon source (Fig. 5). When amorphous Fe(III) oxide or $\mathrm{Fe}$ (III) citrate was present in the medium, the strain coupled the oxidation of glycerol to the reduction of $\mathrm{Fe}$ (III). The

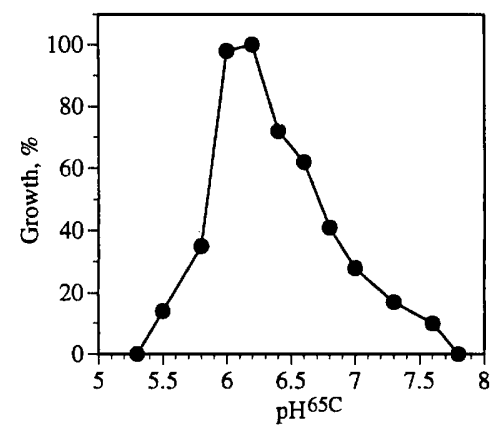

FIG. 4. Effect of $\mathrm{pH}$ on growth of strain JW/AS-Y $7^{\mathrm{T}}$. One hundred percen growth was deemed equivalent to an $\mathrm{OD}_{600}$ of 0.240 after $42 \mathrm{~h}$ of incubation.

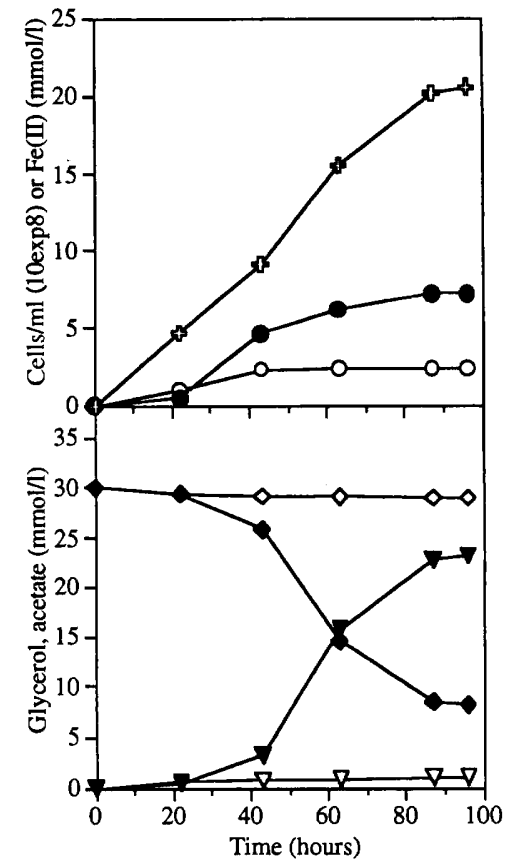

FIG. 5. Growth of, and glycerol consumption and $\mathrm{Fe}$ (II) production by, strain JW/AS-Y $7^{\mathrm{T}}$ grown with and without amorphous Fe(III) oxide as an electron acceptor. Empty circles, cells without Fe(III); filled circles, cells with $\mathrm{Fe}(\mathrm{III})$; crosses, $\mathrm{Fe}(\mathrm{II})$; empty diamonds, glycerol, no $\mathrm{Fe}(\mathrm{III})$; filled diamonds, glycerol and $\mathrm{Fe}(\mathrm{III})$; empty triangles, acetate, no $\mathrm{Fe}(\mathrm{III})$; filled triangles, acetate and $\mathrm{Fe}$ (III).

cell numbers increased with the consumption of glycerol and the concomitant accumulation of $\mathrm{Fe}(\mathrm{II})$. Without an external electron acceptor, growth was weaker, and the maximal cell

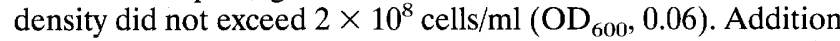
of $0.05 \%$ yeast extract did not significantly stimulate the growth of strain JW/AS-Y7 $7^{\mathrm{T}}$.

Glycerol was oxidized incompletely to acetate in the absence as well as in the presence of $\mathrm{Fe}$ (III). $\mathrm{No}_{2}, \mathrm{CH}_{4}, \mathrm{C}_{1}$ to $\mathrm{C}_{3}$ alcohols, diols, or organic acids, except acetate, were detected in the cultures at any growth stage. In the presence of $\mathrm{CO}_{2}$, the ratio of acetate produced to glycerol consumed was $1.28 \pm 0.3$ (mean \pm standard deviation for five cultures) for strain JW/ AS-Y $7^{\mathrm{T}}$ in cultures with amorphous $\mathrm{Fe}$ (III) oxide or $\mathrm{Fe}$ (III) citrate (growth, $6.3 \times 10^{8}$ cells $/ \mathrm{ml}$ ) and $1.69 \pm 0.3$ (mean \pm standard deviation for five cultures) in cultures without $\mathrm{Fe}(\mathrm{III})$ (growth, $2.0 \times 10^{8}$ cells $/ \mathrm{ml}$ ). With amorphous $\mathrm{Fe}(\mathrm{III})$ oxide or $\mathrm{Fe}$ (III) citrate as an electron acceptor, the ratio of $\mathrm{Fe}$ (II) produced to glycerol consumed was $1.02 \pm 0.4$ (mean \pm standard deviation for five cultures).

Substrate utilization. The substrates utilized by strain JW/ AS-Y $7^{\mathrm{T}}$ in the presence as well as in the absence of $\mathrm{Fe}$ (III) as an electron acceptor included glycerol $(40 \mathrm{mM})$, lactate $(20$ $\mathrm{mM}), 1$,2-propanediol $(20 \mathrm{mM})$, glycerate $(20 \mathrm{mM})$, pyruvate $(20 \mathrm{mM})$, and yeast extract $(5 \mathrm{~g} /$ liter $) . \mathrm{Fe}$ (III) significantly stimulates growth of the strain with all substrates utilized. Poor (change in optical density of 0.04 to 0.05 compared to the control with no added carbon source) but still viable growth was observed in the medium without $\mathrm{Fe}$ (III) supplemented with $25 \mathrm{mM}$ glucose, fructose, or mannose; the consumption of carbohydrates did not exceed $1 \mathrm{mM}$, and the only organic metabolic product formed was acetate. $\mathrm{Fe}$ (III) was chemically reduced by carbohydrates in sterile controls. Thus, the test for carbohydrate utilization in the presence of $\mathrm{Fe}$ (III) is equivocal. In the presence of amorphous Fe(III) oxide or 9,10-anthraqui- 


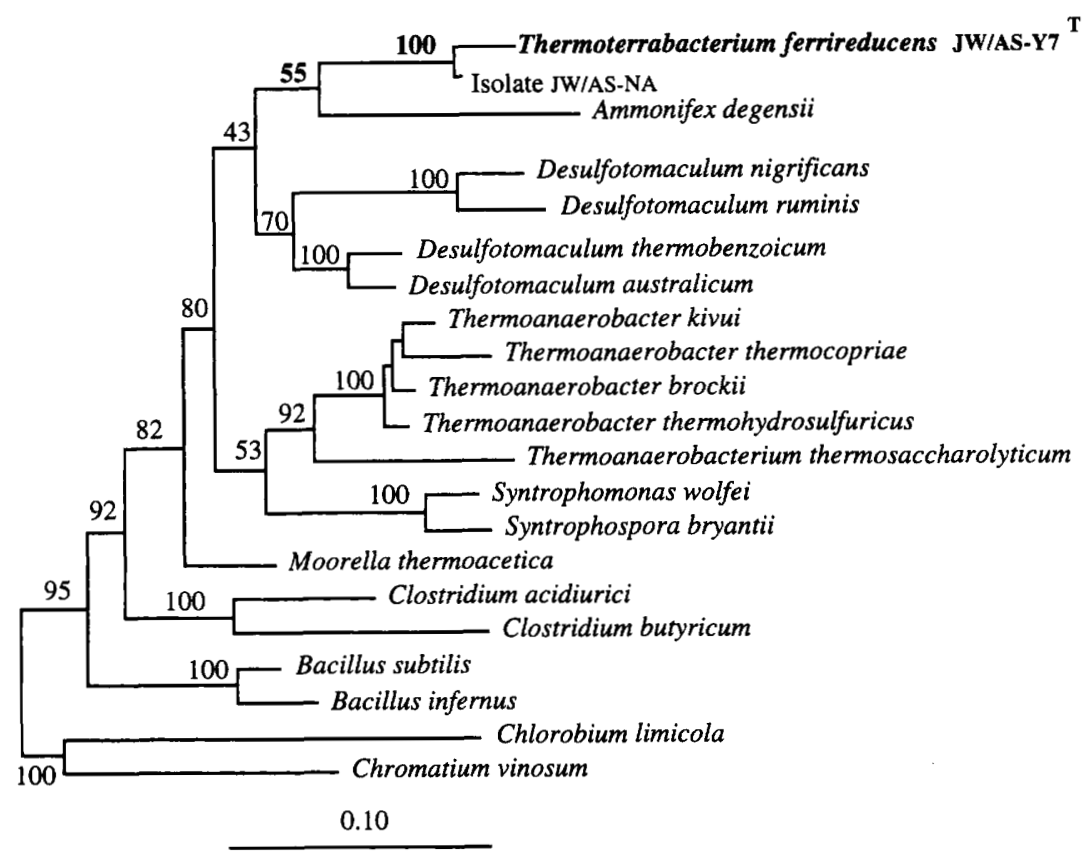

FIG. 6. Phylogenetic tree produced by maximum-likelihood analysis. The scale bar represents the expected number of changes per sequence position. The numbers depict the bootstrap values obtained for a bootstrap sampling of 100 .

none-2,6-disulfonic acid, strain JW/AS-Y $7^{\mathrm{T}}$ grew on $\mathrm{H}_{2}-\mathrm{CO}_{2}$ $(80: 20$ or $5: 95 \%$ [vol/vol]) and utilized molecular hydrogen. Without external electron acceptors, growth on $\mathrm{H}_{2}-\mathrm{CO}_{2}$ and net consumption of $\mathrm{H}_{2}$ were not observed.

Strain JW/AS-Y7 $7^{\mathrm{T}}$ did not utilize formate $(20 \mathrm{mM})$, acetate $(30 \mathrm{mM})$, methanol $(20 \mathrm{mM})$, ethanol $(20 \mathrm{mM}), n$-propanol $(20 \mathrm{mM}), i$-propanol $(20 \mathrm{mM}), n$-butanol $(20 \mathrm{mM})$, propionate $(20 \mathrm{mM})$, acetone $(20 \mathrm{mM})$, ethylene glycol $(20 \mathrm{mM}), 1,3-$ propanediol $(20 \mathrm{mM})$, fumarate $(20 \mathrm{mM})$, succinate $(20 \mathrm{mM})$, phenol $(10 \mathrm{mM})$, benzoate $(20 \mathrm{mM}), 9,10$-anthraquinone-2,6disulfonic acid $(20 \mathrm{mM})$, starch (5 g/liter), olive oil (10 m/liter), precipitated $S^{0}(150 \mathrm{mM})$, sublimated $S^{0}(150 \mathrm{mM})$, sucrose $(25 \mathrm{mM})$, galactose $(25 \mathrm{mM})$, xylose $(25 \mathrm{mM})$, cellobiose (25 $\mathrm{mM})$, or arabinose $(25 \mathrm{mM})$ with or without $\mathrm{Fe}(\mathrm{III})$ as an electron acceptor.

Electron acceptors. Strain JW/AS-Y $7^{\mathrm{T}}$ coupled the oxidation of glycerol to reduction of amorphous $\mathrm{Fe}$ (III) oxide (90 $\mathrm{mM}), \mathrm{Fe}$ (III) citrate $(20 \mathrm{mM})$, fumarate $(10 \mathrm{mM})$, thiosulfate $(20 \mathrm{mM})$, and 9,10-anthraquinone-2,6-disulfonic acid (2.0 $\mathrm{mM}$ ). Fumarate was reduced to succinate. Thiosulfate was reduced to elemental sulfur. Strain JW/AS-Y $7^{\mathrm{T}}$ did not reduce nitrate $(20 \mathrm{mM})$ or sulfate $(20 \mathrm{mM})$ and was not capable of growth with $\mathrm{O}_{2}(20 \%$ [vol/vol] in the gas phase), sulfite $(20$ $\mathrm{mM}), \mathrm{MnO}_{2}(20 \mathrm{mM})$, precipitated $S^{0}(150 \mathrm{mM})$, or sublimated $S^{0}(150 \mathrm{mM})$ with glycerol as an electron donor.

Antibiotic susceptibility. Chloramphenicol, erythromycin, and rifampin completely inhibited growth and $\mathrm{Fe}$ (III) reduction at a concentration of $100 \mu \mathrm{g} / \mathrm{ml}$ of medium. Ampicillin, streptomycin, and tetracycline at $100 \mu \mathrm{g} / \mathrm{ml}$ did not inhibit growth and $\mathrm{Fe}$ (III) reduction.

DNA base composition. The $\mathrm{G}+\mathrm{C}$ content of the genomic DNA of strain JW/AS-Y $7^{\mathrm{T}}$ was $41 \mathrm{~mol} \%$ (as determined by HPLC).

Phylogeny. 16S rDNA sequence analysis indicated that strain JW/AS-Y $7^{\mathrm{T}}$ is a member of the Bacillus-Clostridium subphylum of the Gram-type-positive (eu)bacteria (Fig. 6). Phylogenetic trees based on maximum-likelihood analyses and distance matrices were similar. However, bootstrap values for the position of JW/AS-Y $7^{\mathrm{T}}$ indicated that this position is not yet conclusively resolved. Isolation of closer relatives should help resolve this. Using the available $16 \mathrm{~S}$ rRNA (or rDNA) sequences, similarity matrices generated by the Jukes and Cantor correction (16) as modified by Olsen (35) revealed that JW/AS-Y $7^{\mathrm{T}}$ was $83 \%$ similar to Ammonifex degensii (15), the nearest neighbor.

\section{DISCUSSION}

Strain JW/AS-Y $7^{\mathrm{T}}$ is a facultative $\mathrm{Fe}$ (III) reducer, capable of oxidizing organic substrates in the presence and absence of $\mathrm{Fe}(\mathrm{III})$. This strain represents the first dissimilatory $\mathrm{Fe}$ (III)reducing anaerobic thermophile isolated from a terrestrial geothermal area and is the first example of direct isolation from a thermobiotic environment of an organism that uses $\mathrm{Fe}(\mathrm{III})$ as an electron acceptor. Greater cell numbers were obtained in media containing $\mathrm{Fe}$ (III), suggesting that $\mathrm{Fe}$ (III) reduction may play a role in energy conservation. The observation that no molecular hydrogen was produced during growth under all tested conditions suggests that $\mathrm{Fe}$ (III) reduction is not a detoxification process. While the pathway of glycerol degradation remains unknown, the results obtained do suggest that the isolated organism is an acetogenic bacterium. Based on the obtained stoichiometry, the degradation of glycerol could be described by equation 1 , with reduction of $\mathrm{CO}_{2}$ $(12,34)$, or by equation 2 , with reduction of $\mathrm{CO}_{2}$ and $\mathrm{Fe}$ (III).

$$
\begin{gathered}
4 \mathrm{C}_{3} \mathrm{H}_{8} \mathrm{O}_{3}+2 \mathrm{HCO}_{3}^{-}=7 \mathrm{C}_{2} \mathrm{H}_{3} \mathrm{O}_{2}^{-}+5 \mathrm{H}^{+}+4 \mathrm{H}_{2} \mathrm{O} \\
\Delta \mathrm{G}^{0^{\prime}}=-151.5 \mathrm{~kJ} / \mathrm{mol} \text { of glycerol } \\
8 \mathrm{C}_{3} \mathrm{H}_{8} \mathrm{O}_{3}+2 \mathrm{HCO}_{3}^{-}+8 \mathrm{Fe}_{3}^{+}=13 \mathrm{C}_{2} \mathrm{H}_{3} \mathrm{O}_{2}^{-}+19 \mathrm{H}^{+} \\
\quad+4 \mathrm{H}_{2} \mathrm{O}+8 \mathrm{Fe}^{2+} \\
\Delta \mathrm{G}^{0^{\prime}}=-252.6 \mathrm{~kJ} / \mathrm{mol} \text { of glycerol }
\end{gathered}
$$


TABLE 1. Characteristics that differentiate Thermoterrabacterium ferrireducens from Bacillus infernus

\begin{tabular}{llc}
\hline \multicolumn{1}{c}{ Characteristic } & \multicolumn{1}{c}{ Thermoterrabacterium ferrireducens } & Bacillus infernus \\
\hline Habitat & Hot spring, Yellowstone National Park & Terrestrial subsurface, Virginia \\
Cell size $(\mu \mathrm{m})$ & $0.3-0.4$ by $1.6-2.7$ & $0.7-0.8$ by $4.0-8.0$ \\
Temperature range $\left({ }^{\circ} \mathrm{C}\right)$ & $50-74$ & $39-65$ \\
Temperature optimum $\left({ }^{\circ} \mathrm{C}\right)$ & 65 & 61 \\
$\mathrm{pH}$ range & $5.5-7.6$ & $6.6-9.0$ \\
$\mathrm{pH}$ optimum & $6.0-6.2$ & $7.3-7.8$ \\
$\mathrm{NaCl}$ concn range $(\%)$ & $0-1.0$ & $0-12$ \\
Reduction of: & + & - \\
$\quad$ Thiosulfate & - & + \\
$\quad \mathrm{Nitrate}$ & - & + \\
$\mathrm{MnO}_{2}$ & Acetate & Acetate, lactate, butyrate \\
Product(s) of glucose fermentation & & \\
\hline
\end{tabular}

The process involving $\mathrm{Fe}(\mathrm{III})$ reduction gives a higher yield of energy per mole of glycerol consumed. The relatively high variability of experimental data on acetate/glycerol ratios suggests that the processes of $\mathrm{CO}_{2}$ and $\mathrm{Fe}$ (III) reduction could be competitive, especially in a heterophase system with insoluble amorphous $\mathrm{Fe}$ (III) oxide.

The 16S rDNA sequence analysis places strain JW/AS-Y7 $7^{\mathrm{T}}$ in the Gram-type-positive Bacillus-Clostridium subphylum and thus separates it from the members of the Gram-type-negative family Geobacteriaceae and gamma proteobacteria that accommodate most of the mesophilic dissimilatory Fe(III) reducers. The capacity for dissimilatory $\mathrm{Fe}(\mathrm{III})$ reduction generally has not been tested among thermophilic anaerobes. So far, the only described (eu)bacterial anaerobic thermophile capable of dissimilatory $\mathrm{Fe}$ (III) reduction is $B$. infernus. Strain JW/AS$\mathrm{Y} 7^{\mathrm{T}}$ differs from $B$. infernus in morphology, temperature and $\mathrm{pH}$ ranges and optima, electron acceptors utilized, and products of glucose fermentation (Table 1). On the basis of physiological properties and phylogenetic analysis, we propose that strain JW/AS-Y $7^{\mathrm{T}}$ represents a new species of a new genus.

Description of Thermoterrabacterium gen. nov. Thermoterrabacterium (Ther.mo.ter.ra.bac.te'ri.um. Gr. adj. thermos, hot; L. n. terra, land, earth; Gr. neut. n. bacterion, a small rod; M. L. neut. n. Thermoterrabacterium, rod-shaped bacterium from heated land). Rod-shaped, Gram-type-positive (eu)bacteria. Anaerobic and thermophilic. Neutrophilic. Facultative Fe(III) reducers. Able to couple the dissimilatory reduction of $\mathrm{Fe}$ (III) with oxidation of polyols and organic acids. In the presence of $\mathrm{Fe}(\mathrm{III})$ organic substrates are oxidized incompletely to acetate as the main metabolic product. Saccharolytic. Do not reduce sulfate.

Description of Thermoterrabacterium ferrireducens sp. nov. Thermoterrabacterium ferrireducens [fer.ri.re.du'cens. L.n. ferrum, iron; L. part. adj. reducens, converting to a different state; M. L. adj. ferrireducens, reducing iron (III)]. Straight to slightly curved rods, 0.3 to 0.4 by 1.6 to $2.7 \mu \mathrm{m}$ with rounded ends. Cells stain gram positive. Occurring singly or in pairs. Exhibits a tumbling motility. Spores were not observed. Anaerobic. Grows on simple, defined medium. The temperature range for growth is 50 to $74^{\circ} \mathrm{C}$ with the optimum being $65^{\circ} \mathrm{C}$. The $\mathrm{pH}^{65 \mathrm{C}}$ range for growth is from 5.5 to 7.6, with an optimum at 6.0 to 6.2. Growth occurs in the $\mathrm{NaCl}$ concentration range of 0 to $1.0 \%(\mathrm{wt} / \mathrm{vol})$. In the presence of $\mathrm{CO}_{2}$, strain JW/AS-Y $7^{\mathrm{T}}$ is able to grow with glycerol as the only organic carbon source. Couples the oxidation of glycerol to reduction of amorphous $\mathrm{Fe}$ (III) oxide or Fe(III) citrate as an electron acceptor, forming $\mathrm{Fe}$ (II) as magnetite and siderite. In the presence as well as in the absence of $\mathrm{Fe}(\mathrm{III})$, and in the presence of $\mathrm{CO}_{2}$, glycerol is oxidized incompletely to acetate as the only organic meta- bolic product, leading to a ratio of more than one acetate molecule produced per glycerol molecule consumed. Does not produce $\mathrm{H}_{2}$. Utilizes glycerol, lactate, 1,2-propanediol, glycerate, pyruvate, and yeast extract. Grows weakly on glucose, fructose, and mannose, producing acetate as the only organic product. In the presence of $\mathrm{Fe}$ (III) utilizes molecular hydrogen. No growth occurs with formate, acetate, methanol, ethanol, $n$-propanol, $i$-propanol, $n$-butanol, propionate, acetone, ethylene glycol, 1,3-propanediol, fumarate, succinate, phenol, benzoate, 9,10-anthraquinone-2,6-disulfonic acid, starch, olive oil, elemental sulfur, sucrose, galactose, xylose, cellobiose, or arabinose, with or without Fe(III). Reduces 9,10-anthraquinone-2,6-disulfonic acid, fumarate to succinate, and thiosulfate to elemental sulfur. Does not reduce $\mathrm{MnO}_{2}$, nitrate, sulfate, sulfite, or elemental sulfur. Growth is inhibited by chloramphenicol, erythromycin, and rifampin at $100 \mu \mathrm{g} / \mathrm{ml}$ but not by ampicillin, streptomycin, or tetracycline. DNA base composition is $41 \mathrm{~mol} \% \mathrm{G}+\mathrm{C}$ (HPLC). The habitat is freshwater hot springs such as Calcite Springs in Yellowstone National Park, Wyoming.

The type strain and, so far, the only isolated strain is JW/ AS- $Y 7^{\mathrm{T}}$, which has been deposited with the Deutsche Sammlung von Mikroorganismen und Zellkulturen GmbH under accession number DSM 11255.

\section{ACKNOWLEDGMENTS}

This work was supported by a grant to J.W. from Genencor International.

We thank F. Mayer and M. Hoppert for electron microscopy, $\mathrm{H}$ Trüper for help with the correct derivation of latinized names, and $\mathbf{J}$. Spina for technical assistance. We are grateful for the sequencing and phylogenetic analysis assistance provided by J. Kirshtein and P. Rivera.

\section{REFERENCES}

1. Balashova, V. V., and G. A. Zavarzin. 1980. Anaerobic reduction of ferric iron by hydrogen bacteria. Microbiology 48:635-639.

2. Boone, D. R., Y. Liu, Z.-J. Zhao, D. L. Balkwill, G. R. Drake, T. O. Stevens, and H. C. Aldrich. 1995. Bacillus infernus sp. nov., an Fe(III)- and Mn(IV)reducing anaerobe from the deep terrestrial subsurface. Int. J. Syst. Bacteriol. 45:441-448.

3. Brock, T. D., and J. Gustafson. 1976. Ferric iron reduction by sulfur- and iron-oxidizing bacteria. Appl. Environ. Microbiol. 32:567-571.

4. Caccavo, F., Jr., R. P. Blakemore, and D. R. Lovley. 1992. A hydrogenoxidizing, Fe(III)-reducing microorganism from the Great Bay estuary, New Hampshire. Appl. Environ. Microbiol. 58:3211-3216.

5. Caccavo, F., Jr., D. J. Lonergan, D. R. Lovley, M. Davis, J. F. Stolz, and M. J. McInerney. 1994. Geobacter sulfurreducens sp. nov, a hydrogen- and acetateoxidizing dissimilatory metal reducing microorganism. Appl. Environ. Microbiol. 60:3752-3759.

6. Caccavo, F., Jr., J. D. Coates, R. A. Rosselo-Mora, W. Ludwig, K. H. Schleifer, D. R. Lovley, and M. J. McInerney. 1996. Geovibrio ferrireducens, a phylogenetically distinct dissimilatory Fe(III)-reducing bacterium. Arch. Microbiol. 165:370-376. 
7. Coates, J. D., D. J. Lonergan, E. J. P. Philips, H. Jenter, and D. R. Lovley, 1995. Desulfuromonas palmitatis sp. nov., a marine dissimilatory $\mathrm{Fe}$ (III) reducer that can oxidize long-chain fatty acids. Arch. Microbiol. 164:406-413.

8. Cord-Ruwisch, R. 1985. A quick method for the determination of dissolved and precipitated sulfides in cultures of sulfide-reducing bacteria. J. Microbiol. Methods 4:33-36

9. De Soete, G. 1983. A least squares algorithm for fitting additive trees to proximity data. Psychometrika 48:621-626.

10. Doetsch, R. N. 1981. Determinative methods of light microscopy, p. 21-33. In P. Gerhardt, R. G. E. Murray, R. N. Costilow, E. W. Nester, W. A. Wood, N. R. Krieg, and G. B. Phillips (ed.), Manual of methods for general microbiology. American Society for Microbiology, Washington, D.C.

11. Durand, P., A. L. Reysenbach, D. Prieur, and N. Pace. 1993. Isolation and characterization of Thiobacillus hydrothermalis sp. nov., a mesophilic obligately chemolithotrophic bacterium isolated from a deep-sea hydrothermal vent in Fiji Basin. Arch. Microbiol. 159:39-44.

12. Eichler, B., and B. Schink. 1984. Oxidation of primary aliphatic alcohols by Acetobacterium carbinolicum sp. nov., a homoacetogenic anaerobe. Arch. Microbiol. 140:147-152.

13. Gold, T. 1992. The deep, hot biosphere. Proc. Natl. Acad. Sci. USA 89:60456049.

14. Gow, P. A., V. F. Wall, N. H. S. Oliven, and R. K. Valenta. 1994. Proterozoic iron oxide (Cu-U-Au-REF) deposits: further evidence of hydrothermal origin. Geology 22:633-637.

15. Huber, R., P. Rossnagel, C. R. Woese, R. Rachel, T. A. Langworthy, and K. O. Stetter. 1996. Formation of ammonium from nitrate during chemolithoautotrophic growth of the extremely thermophilic bacterium Ammonifex degensii gen. nov. sp. nov. Syst. Appl. Microbiol. 19:40-49.

16. Jukes, T. H., and C. R. Cantor. 1969. Evolution of protein molecules, p. 21-132. In H. N. Munro (ed.), Mammalian protein metabolism. Academic Press, New York, N.Y.

17. Ljungdahl, L. G., and J. Wiegel. 1986. Working with anaerobic bacteria, p. 84-96. In A. L. Demain and N. A. Solomon (ed.), Manual of industrial microbiology and biotechnology. American Society for Microbiology, Washington, D.C.

18. Lonergan, D. J., H. L. Jenter, J. D. Coates, E. J. P. Phillips, T. M. Schmidt, and D. R. Lovley. 1996. Phylogenetic analysis of dissimilatory $\mathrm{Fe}$ (III)-reducing bacteria. J. Bacteriol. 178:2402-2408.

19. Lovley, D. R. 1991. Dissimilatory Fe(III) and Mn(IV) reduction. Microbiol. Rev. 55:259-287

20. Lovley, D. R., S. J. Giovannoni, D. C. White, J. E. Champine, E. J. P. Phillips, Y. A. Gorby, and S. Goodwin. 1993. Geobacter metallireducens gen. nov. sp. nov., a microorganism capable of coupling the complete oxidation of organic compounds to the reduction of iron and other metals. Arch. Microbiol. 159:336-344.

21. Lovley, D. R. 1995. Microbial reduction of iron, manganese, and other metals. Adv. in Agron. 54:175-231.

22. Lovley, D. R., E. J. P. Phillips, D. J. Lonergan, and P. K. Widman. 1995. $\mathrm{Fe}(\mathrm{III})$ and $\mathrm{S}^{0}$ reduction by Pelobacter carbinolicus. Appl. Environ. Microbiol. 61:2132-2138.
23. Marmur, J. 1961. A procedure for the isolation of desoxyribonucleic acid from microorganisms. J. Mol. Biol. 3:208-218.

24. Mesbah, M., U. Premachandran, and W. B. Whitman. 1989. Precise measurement of the $\mathrm{G}+\mathrm{C}$ content of deoxyribonucleic acid by high-performance liquid chromatography. Int. J. Syst. Bacteriol. 39:159-167.

25. Nealson, K. H., and D. Saffarini. 1994. Iron and manganese in anaerobic respiration: environmental significance, physiology, and regulation. Annu. Rev. Microbiol. 48:311-343.

26. Olsen, G. J., H. Matsuda, R. Hagstrom, and R. Overbeek. 1994. fastDNAml: a tool for construction of phylogenetic trees of DNA sequences using maximum likelihood. Comput. Appl. Biosci. 10:41-48.

27. Rosselo-Mora, R. A., F. Caccavo, K. Osterlehner, N. Springer, S. Spring, D. Schuler, W. Ludwig, R. Amann, M. Vanncanneyt, and K. H. Schleifer. 1994 Isolation and taxonomic characterization of a halotolerant, facultatively ironreducing bacterium. Syst. Appl. Microbiol. 17:569-573.

28. Rosselo-Mora, R. A., W. Ludwig, P. Kampfer, R. Amann, and K. H. Schleifer. 1995. Ferrimonas balearica gen. nov., sp. nov., a new marine facultative Fe(III)-reducing bacterium. Syst. Appl. Microbiol. 18:196-202.

29. Semple, K., and D. Westlake. 1987. Characterization of iron-reducing Alteromonas putrefaciens strains from oil field fluids. Can. J. Microbiol. 33:366371.

30. Slobodkin, A., and J. Wiegel. Fe(III) as an electron acceptor for $\mathrm{H}_{2}$ oxidation in thermophilic anaerobic enrichment cultures from geothermal areas. Extremophiles, in press.

31. Slobodkin, A. I., V. A. Eroshchev-Shak, N. A. Kostrikina, V. Y. Lavrushin L. G. Dainyak, and G. A. Zavarzin. 1995. Magnetite formation by thermophilic anaerobic microorganisms. Dokl. Akad. Nauk 345:694-697. (In Russian.)

32. Spurr, A. R. 1969. A low-viscosity epoxy resin embedding medium for electron microscopy. J. Ultrastruct. Res. 26:31-43.

33. Svetlitshnyi, V., F. Rainey, and J. Wiegel. 1996. Thermosyntropha lipolytica gen. nov., sp. nov., a lipolytic, anaerobic, alcalitolerant, thermophilic bacterium utilizing short- and long-chain fatty acids in syntrophic coculture with a methanogen archaeum. Int. J. Syst. Bacteriol. 46:1131-1137.

34. Thauer, R. K., K. Jungermann, and K. Decker. 1977. Energy conservation in chemotrophic anaerobic bacteria. Bacteriol. Rev. 41:100-180.

35. Weisburg, W. G., J. G. Tully, D. L. Rose, J. P. Petzel, H. Oyaizu, D. Yang, L. Mandelco, J. Sechrest, T. G. Lawrence, J. Van Etten, J. Maniloff, and C. R. Woese. 1989. A phylogenetic analysis of the mycoplasmas: basis for their classification. J. Bacteriol. 171:6455-6467.

36. Whitman, W. B., S. Sohn, D. S. Caras, and U. Premachandran. 1986. Isolation and characterization of 22 mesophilic methanococci. Syst. Appl. Microbiol. 7:235-240.

37. Wiegel, J. 1981. Distinction between the Gram reaction and the Gram type of bacteria. Int. J. Syst. Bacteriol. 31:88

38. Wiegel, J., and L. Quandt. 1982. Determination of the Gram type using the reaction between polymyxin $B$ and lipopolysaccharides of the outer cell wall of whole bacteria. J. Gen. Microbiol. 128:2261-2270.

39. Wolin, E. A., M. J. Wolin, and R. S. Wolfe. 1963. Formation of methane by bacterial extracts. J. Biol. Chem. 238:2882-2886. 